\title{
COMPARISON BETWEEN SENSORY AND INSTRUMENTAL MEASUREMENTS FOR MEALINESS ASSESSMENT IN APPLES. A COLLABORATIVE TEST
}

\author{
P. BARREIRO , C. ORTIZ , M. RUIZ-ALTISENT , V. DE SMEDT , S. SCHOTTE , \\ Z. ANDANI, I. WAKELING and P.K. BEYTS
}

Physical Properties Lab

Rural Engineering Dept.

College of Agriculture (ETSIA)

Polytechnic University of Madrid (UPM)

Avda. Complutense s/n. 28.040 Madrid, Spain

Department of Agro-Engineering and Economics

Catholic University of Leuven $(\mathrm{KU})$

Kard. Mercierlaan 92. B-3001 Heverlee Belgium

Institute of Food Research (IFR)

Earley Gate, Whiteknights Road RG6 2EF Reading

United Kingdom

Sensory Dimensions ( $S D$ )

Reading University Innovation Centre

Philip Lyle Building, P.O. Box 68

Whiteknights, Reading RG6 2BX United Kingdom

(Manuscript received Decenber 8, 1997; in final form May 18, 1998)

\begin{abstract}
Definition and establishment of assessment procedures for mealiness of apple fruits using sensory and instrumental measurements were performed on 'Boskoop'. 'Cox's Orange Pippin' and 'Jonagold' samples with varying degrees of mealiness. The sensory procedure profiled mealiness as a loss of crispness, hardness, and juiciness, with an increase in the floury sensation in the mouth. High correlations between the sensory descriptors and instrumental parameters was shown through principal component analysis. The instrumental procedures (confined compression of fruit cylinders and acoustic impulse response) gave coefficients of determination for juiciness and crispness of 0.85 and 0.71 , respectively. This level of accuracy indicates the possibility of establishing
\end{abstract}


several commercial mealiness stages (as lack of crispness and of juiciness) based on instrumental analyses.

\section{INTRODUCTION}

Texture is an aspect of the consistency of the vegetative tissue determined by the way the cells are joined by the middle lamella. When a load is applied to the plant tissues with a strong middle lamella, the cell walls break preferentially (Sone 1972; Haard and Salunkhe 1975), liberating juice giving a sensory sensation of crispiness and juiciness. When the middle lamelia has been weakened by the action of pectin degrading enzymes breakage occurs in the middle lamella without cell rupture and juice liberation (Sone 1972; Haard and Salunkhe 1975) so a mealy fruit is nonjuicy to the consumer. In addition, there is a higher percentage of intercellular spaces filled with air rather than juice in mealy apples when compared to nonmealy apples (Harker and Hallet 1992) indicating the importance of free water in the juiciness sensation. Occursence of mealiness in apples is associated with cultivar (Lapsley et al. 1992) and with late harvest combined with cold storage. Development of mealiness during long term cold storage is variable (Harker and Hallet 1992).

Abbott et al. (1984) studied the relationship among selected sensory textural attributes and data from texture profiles (force-deformation curves) obtained from compression of tissue cylinders and found that the combination of several variables of the texcure profiles in regression equations improved prediction of sensory attributes when compared to single parameters. Mealiness appeared to be the worst fitted sensory attribute while crispness and hardness were the best fitted sensory parameters.

Harker and Hallet (1992) showed that a segregation of 'Braeburn' apples by background colour led to significant differences in mealiness onset after 16 weeks of cold storage (from $20 \%$ to $80 \%$ of mealy fruits). The greatest differences at harvest for these batches of apples were found for the soluble solid content (higher for the most mealy susceptible apples), for the cell wall content (higher for most susceptible apples), and for compression ruplure test (maximum force from $84 \mathrm{~N}$ for the less susceptible to $76.9 \mathrm{~N}$ for the most mealiness susceptible appies).

Paoletti et al. (1993) found a high correlation between sensory mealiness and instrumental cohesiveness $(R=-0.704)$ and juiciness $(R=-0.744)$ in different apple cultivars, assessing both instrumental parameters on fruit probes. The Magness-Taylor penetration test and the instrumental hardness were less related to sensory mealiness.

Barreiro and Ruiz-Altisent (1996) showed that apple cylinders could be used to segregate three types of textural groups of fruits: elastic, plastic and mealy. 
Besides the interest of achieving a destructive reference test for mealiness assessment, nondestructive techniques should be developed. Acoustic vibration techniques provide a good perspective in apples as they have shown a high correlation with several mechanical attributes such as the elasticity modulus (Armstrong et al. 1990) or the maximum compression force in compression or puncture (Abbott et al. 1995). Finally, Harker et al. (1997) indicate that the validity of an instrumental measurement of texture should be based on how well it predicts sensory analysis. In this sense the shape of the force-deformation curve along with maximum force were able to provide comprehensive characterization of texture.

The objective of this study was to define the sensory perception of mealy texture in apples and to use this definition to identify optimum instrumental procedures for mealiness assessment.

\section{MATERIAL AND METHODS}

\section{Material}

A factorial design with two factors: variety and mealiness stage were chosen:

(1) varieties: 'Boskoop', 'Cox s Orange Pippin' and 'Jonagold'

(2) mealiness stages: three degrees corresponding to a combination of harvest date and room temperature conditions (95\% R.H. and 20C).

No more than ten apples ( $1 / 4$ of apple) could be assessed by each member of the sensory panel during one session. A sample size of six fruits where each fruit was tasted by two panellists. Therefore only 1 average sensory measurement was achieved for every 6 fruits, that is, per sample.

Three replicates were carried out over one week. Thus 9 samples $* 6$ fruits/sample * 3 replicates $=162$ fruits ( $40 \mathrm{~kg}$ approx.) were used in this experiment. The samples were provided by V.B.T (Verbond van Belgische Tuinbouwveilingen). The material provided by VBT showed a high variability in mealiness onset as expected. Remarks on their firmness and their sugar content at harvest was included in the labelling of the samples (see Table 1). The apples were removed from cold storage $(3 \mathrm{C} \pm 0.5 \mathrm{C}) 7-12 \mathrm{~h}$ before any sensory or instrumental assessment.

\section{Methods}

The tests were carried out in the following order: 
Acoustic Impulse Response Technique (KU Leuven). The test was performed with KULART (Galili and Baerdemaeker 1996). The system records in the frequency range of 200 to $1600 \mathrm{~Hz}$. Each apple was hit by a little rod at three different points on the equator, and the resonance frequency (FREQ) recorded by means of a microphone. After correction for the fruit weight (WEIGHT, which was measured by a scale) the resonance frequency is used to calculate the stiffness index (STIFF) as FREQ $^{2 * W E I G H T}{ }^{2 / 3}$. Therefore 3 parameters were obtained through this test.

TABLE 1.

MATERIAL DESCRIPTION AND ENCODING EMPLOYED FOR THE CURRENT RESEARCH. 'THE MATERIAL WAS PROVIDED BY V.B.T. IIRMNESS AND SOLUBLE SOIJD CONTENT REIEER TO TIIE MATURITY STAGE OF THE SAMPLES AT THE TIME OF HARVEST.

\begin{tabular}{ccccc} 
Variety & Date of harvest & $\begin{array}{c}\text { Mealiness } \\
\text { enhancement } \\
\text { duration } \\
\text { (weeks) }\end{array}$ & $\begin{array}{c}\text { Firmness at } \\
\text { larvest } \\
\text { Magness- } \\
\text { Taylor } \\
(\mathrm{N})\end{array}$ & $\begin{array}{c}\text { Solutble solids content at } \\
\text { larvest ("BRIX) }\end{array}$ \\
\hline Boskoop & $25-9-96$ & 0 & 78.40 & 11.6 \\
& $30-9-96$ & 1 & $70.56^{\circ}$ & 12.4 \\
Cox & $11-10-96$ & 2 & 61.74 & 13.3 \\
& $23-9-96$ & 0 & 73.50 & 12.5 \\
& $30-9-96$ & 1 & 65.66 & 13.6 \\
Jonagold & $4-10-96$ & 2 & 51.94 & 14.0 \\
& $2-10-96$ & 0 & 70.56 & 12.8 \\
& $15-10-96$ & 1 & 59.78 & 13.9 \\
\hline
\end{tabular}

Sensory Protocol (IFR + SD). The panrel consisted of 12 females between the ages of 30 and 60 . On the first day, a discussion was held to select descriptors that would adequately characterise the sensory characteristics of the nine saniples ( 3 varieties*3 mcaliness stages). Sensory tests were performed over the next two days. The apple samples were pecled, quartered and cored, and presented on coded plastic coated white paper plates; the samples were balanced for order and carry-over effects. The panellists were requested 10 eat dry crackers and drink water between samples to cleanse their palates. For profiling, 
each panellist was presented with a quarter of an apple in a taste booth where the light, temperature, humidity and noise are controlled. Each panellist was asked to rate the list of 41 sensory attributes (Table 2) generated in the discussion session, at their own pace, and to record their results using the sensory compuler programme Taste (MacFje and Bratchell 1989; DaillantSpinnler et al. 1996).

TABLE 2.

SENSORY DESCRIPTORS USED BY THE TRAINED PANEL. EACH ATTRIBUTE WAS EVALUATED WITHIN A 100 DEGREE SCALE FROM $\because$ TO 99. BOLD DESCRIPTORS WERE USED FOR PRINCIPAL COMPONENT ANALYSIS

\begin{tabular}{|c|c|c|c|}
\hline & $\begin{array}{l}\text { SENSURY } \\
\text { DESCRIPTOR }\end{array}$ & & $\begin{array}{l}\text { SENSORY } \\
\text { DESCRIPTOR }\end{array}$ \\
\hline $\begin{array}{l}\text { TEXT'URE } \\
\text { | st bite }\end{array}$ & $\begin{array}{l}\text { 1. Juiciness } \\
\text { 2. Hardness }\end{array}$ & $\begin{array}{l}\text { FtAVaUR } \\
\text { chewing (cont) }\end{array}$ & $\begin{array}{l}\text { 22. Plum/cherry } \\
\text { 23, Unripe apple }\end{array}$ \\
\hline chewing & $\begin{array}{l}\text { 3, Crispiness } \\
\text { 4, Juiciness } \\
\text { 5, Toughntss/Chewiness }\end{array}$ & & $\begin{array}{l}\text { 24, Pear-like } \\
25, \text { Cox -like } \\
26, \text { Cooked apple }\end{array}$ \\
\hline & $\begin{array}{l}\text { 6, Density of Iesh } \\
\text { 7, Fibrous } \\
\text { 8, Grutultar } \\
\text { 9, Floury } \\
\text { 10, Puipy } \\
\text { 11, Slinyy }\end{array}$ & Afterswallow & $\begin{array}{l}\text { 27, Bitter } \\
\text { 28, Astringent } \\
\text { 29, Drying } \\
\text { 30, Residue }\end{array}$ \\
\hline \multirow[t]{2}{*}{$\begin{array}{l}\text { ELAVOUR } \\
\text { thetying }\end{array}$} & $\begin{array}{l}\text { 12. Green apple } \\
\text { 13, Red apple } \\
\text { 14, Sweet } \\
\text { 15, Aeidicisour } \\
\text { 16. Bitter } \\
\text { 17, Stale }\end{array}$ & $\begin{array}{l}\text { INTERNAL } \\
\text { APPEARANCE }\end{array}$ & $\begin{array}{l}\text { 31. White } \\
32, \text { Green } \\
\text { 33, Yellow } \\
\text { 34. Green Jines } \\
\text { 35, Jutey } \\
\text { 36, Fluffy }\end{array}$ \\
\hline & $\begin{array}{l}\text { 18. Pear Drops } \\
\text { 19. Floral } \\
\text { 20, Watery } \\
\text { 21, Off Flavout }\end{array}$ & INTERNAL ODOUR & $\begin{array}{l}\text { 37, Grassy } \\
38 \text {. Unripe } \\
\text { 39, Damp twigs } \\
\text { 40. Pears } \\
\text { 41, Cooked apple }\end{array}$ \\
\hline
\end{tabular}

Confined Compression Test (UPM). Using a Texture Analyser TA-XT2 a maximum deformation of $2.5 \mathrm{~mm}$ was applied at $20 \mathrm{~mm} / \mathrm{min}$ on cylindrical specimens of $1.7 \mathrm{~cm}$ height and diameter. 'They were decompressed at the same speed rate. Cylinders were contined in a disk which had a hole of the probe size (see Fig. 1). The rod employed for the compression test was $15.3 \mathrm{~mm}$ dianeter to avoid any contact with the disk during testing. A filter paper (Albet ${ }^{\circ} 1305$ of $78 \mathrm{~g} / \mathrm{m}^{2}$ ) about the size of the disk was placed beneath the disk in order to recover the juice extracted during the compression test. 


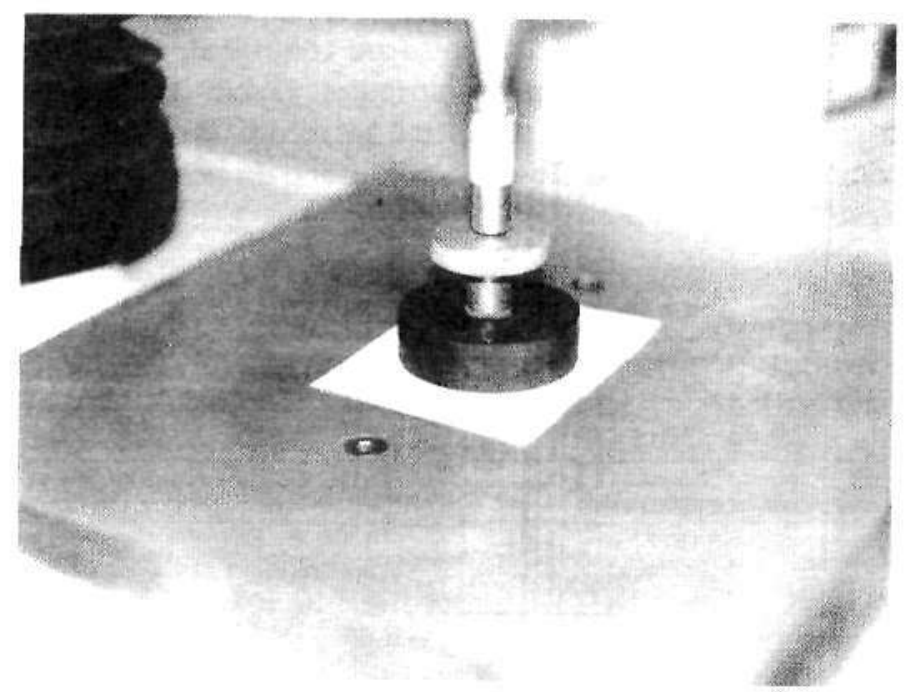

FIG. 1. CONFINED COMPRESSION TEST ON FRUIT CYLINDERS

The following parameters (the name within brackets refers to later nickname of the variables) are registered through this test: Maximum force $(\mathrm{F} 1, \mathrm{~N})$, first peak with $0.5 \mathrm{~N}$ threshold; Deformation for F1 (D1, mm); Hardness (FD1, $\mathrm{N} / \mathrm{mm}$ ) force-deformation slope for F1 and D1; Force for $2.5 \mathrm{~mm}(\mathrm{~F} 2, \mathrm{~N})$; Elastic deformation (ELAS, mm), recoverable deformation after compression; Degree of permanent deformation (PERM, mm), calculated as 100 minus the percentage of elastic deformation (2.5mm); Absorbed energy during compression (AREA 1), area below the force-deformation loading curve; Restitution elastic energy after compression (AREA2), area below the force-deformation unloading curve; Slope F2/DELAS (GRAD 2:3); and Juice area (JUICE, $\mathrm{mm}^{2}$ ) recovered in the filter paper placed underneath the probe during the test.

Ultrasonic Wave Propagation (KU Leuven). The tests were performed with an USD $10 \mathrm{NF}$ system from Krautkramer, using 2 probes (true transmission technique) at $50 \mathrm{khz}$. Samples of 15 and $11 \mathrm{~mm}$ height and $17 \mathrm{~mm}$ diameter were cut by means of a cork borer. Plexiglas adapters were used to concentrate the wave and obtain a higher input signal. The following parameters were registered through the test: transmission time (microseconds) and amplitude of the received wave $(\mathrm{dB})$. With these parameters the velocity of the waves (VEL) inside the material was calculated (Mizrach et al. 1989). 


\section{Data Analysis}

Principal Conponent Analysis was used to compute the relationship between sensory and instrumental parameters. The principal components with eigenvalues above I were used because eigenvalues below I are less explicative than single original variables. The cumulative determination coefficient of instrumental and sensory variables was used to recognise the percentage of representation of variables by the principal components in those cases where no major contribu* tion to a single factor is found. Stepwise multilinear regression was used to model sensory attributes out of instrumental parameters.

\section{RESULTS AND DISCUSSION}

\section{Variability of the Sensory Descriptors}

Of the $4 \mathrm{l}$ sensory descriptors, 19 were identified to be the most relevant ones by the sensory panel on the basis of the standard deviation: better evaluation for wider standard deviation as the samples were selected in order to cover a wide range of mealiness stages (see Fig. 2): juiciness (1) and hardness (2) at first bite, crispness (3), juiciness (4), toughness (5), density of flesh (6), fibrous (7), granular (8) and floury (9) sensations during chewing, green (12) and red (13) apple flavour, sweet (14), acidic (15), stale (17), watery flavour (20), unripe apple flavour (23), astringent flavour after-swallow (28), and yellow (33) and juicy (35) internal appearances.

\section{Description of the Mealy Treatment and Variety Effects}

Sensory and instrumental characteristics of the material are summarised in Table 3. The number of items per average at instrumental parameters is 6 times the number of items per average computed for the sensory attributes because only I sensory measurement was oblained per sample (6 fruits) while the instrumental measurements are performed on individual fruits. Therefore, the standard deviation of the sensory data does not give any information of the inherent variability of the characteristics of fresh fruits.

Increasing mealiness development is associated with decreasing sensory hardness and juiciness. ANOVA indicates that sensory characteristics as acidity are more affected by variety than by the mealiness level itself (though both are significant at $1 \%$ level), while for sensory hardness it is the opposite. Sinular results for sensory and instrumental werc obtained for the ANOVA indicating that both methods are able to segregate between cultivars and stages of mealiness development. For both sensory and instrumental hardness, the effect of the mealiness level is greatest despite the cultival effect, while both sensory and 
instrumental juiciness are more affected by the cultivar effect than by the mealiness level.

Sensory Evaluation Range for sensory descriptors 1 to 41

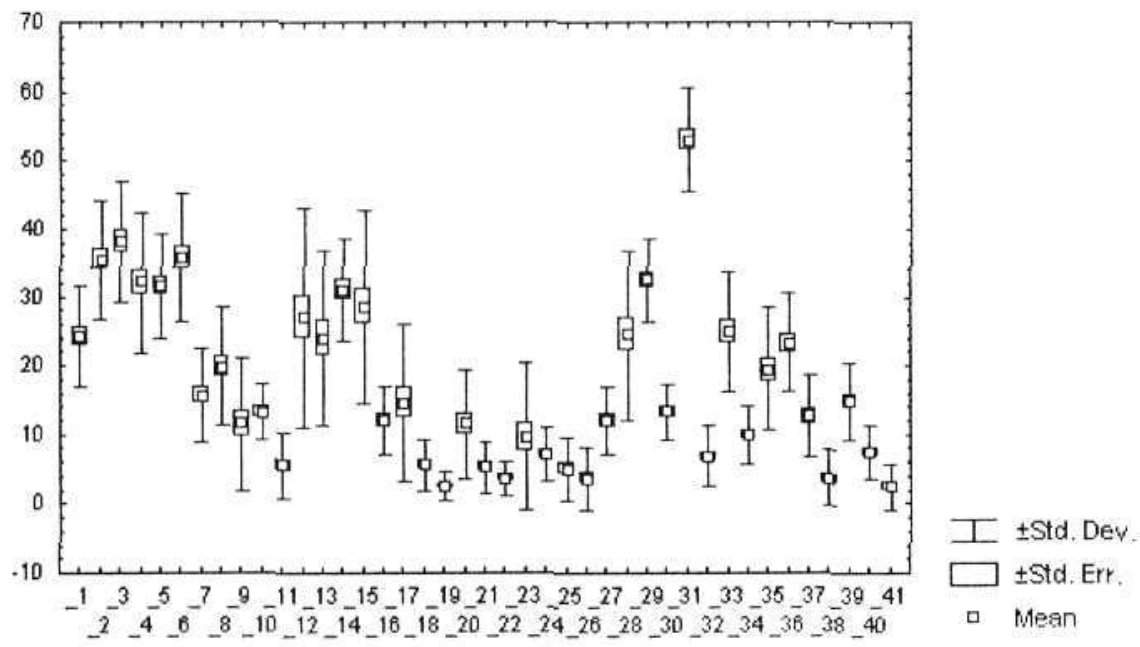

FIG. 2. RANGE OF VARIABILITY OF THE SENSORY DESCRIPTORS FOR THE TOTAI, NUMBER OF 27 SAMPLES ( 3 VARIETIES * 3 MEALINESS STAGES * 3 REPETITIONS)

The numbers refer to the descriptors indicated in Table 2 .

\section{Instrumental Measurements Versus Sensory Mealiness Descriptors}

Principal Component Analysis was carried out on the 27 averages (3 varieties * 3 mealiness stages $* 3$ replicates) 19 selected sensory descriptors plus the 14 instrumental to analyse the relationships between them. The results are summarised as follows:

Within the first three principal components (PC) 78\% of the total variance can be explained (see Table 4).

The 1st PC gathers textural parameters both instrumental and sensory with correlation coefficients higher than 0.80 (see Table 4). Those parameters can be summarised as follows.

Instrumental: from Confined Compression. Maximum force (F1), instrumental hardness (FD1), maximum force at $2.5 \mathrm{~mm}$ deformation (F2), absorbed energy during compression (AREA 1), restitution energy after compression (AREA 2) and F2-elatic deformation ratio (Grad 2:3).

Instrumental: from Acoustic Impulse Response. Stiffness (STIFF). 
Sensory Descriptors. Hardness (2), crispiness (3), density (6), floury (9) and the internal yellow colour of pulp (33); the highest contribution to the first principal component from all the sensory texture attributes corresponds to crispness $(\mathrm{R}=0.88)$.

TABLE 3.

AVERAGE VALUES, STANDARD DEVIATIONS AND NUMBER OF OBSERVATIONS FOR SEVERAL SENSORY AND INSTRUMENTAL MEASUREMENTS. COLUMNS MARKED WITH ** REFER TO 1\% SIGNIFICANCE LEVEL UNDER ANALYSIS OF VARIANCE.

\begin{tabular}{|c|c|c|c|c|c|c|}
\hline & \multicolumn{3}{|l|}{ SENSORY } & \multicolumn{3}{|c|}{ INSTRUMENTAL } \\
\hline & $\begin{array}{l}\text { hardness } \\
\text { (2) }\end{array}$ & $\begin{array}{l}\text { Ist bite } \\
\text { juiciness } \\
\text { (4) }\end{array}$ & $\begin{array}{l}\text { acidic } \\
\text { (15) }\end{array}$ & $\begin{array}{l}\text { hardness } \\
\text { (FDI) }\end{array}$ & $\begin{array}{l}\text { juice area } \\
\text { (JUICE) }\end{array}$ & $\begin{array}{l}\text { stiffness } \\
\text { (STIFF) }\end{array}$ \\
\hline \multicolumn{7}{|l|}{ BOSKOOP } \\
\hline \multirow[t]{3}{*}{ mealy level 1} & 46 & 37 & 54 & 31.6 & 4.87 & 21.4 \\
\hline & 4 & 1 & 7 & 4,3 & 1.20 & 2.3 \\
\hline & 3 & 3 & 3 & 18 & 18 & 18 \\
\hline \multirow[t]{3}{*}{ mealy level 2} & 35 & 26 & 45 & 25.4 & 3.82 & 10.2 \\
\hline & 5 & 4 & 0 & 5.5 & 0.82 & 3.2 \\
\hline & 3 & 3 & 3 & 18 & 18 & 18 \\
\hline \multirow{3}{*}{ mealy level 3} & 36 & 21 & 38 & 18.3 & 2.57 & 4.1 \\
\hline & 3 & 1 & 2 & 5.5 & 0.64 & 0.9 \\
\hline & 3 & 3 & 3 & 18 & 18 & 18 \\
\hline \multicolumn{7}{|l|}{$\operatorname{cox}$} \\
\hline \multirow{3}{*}{ mealy level I } & 39 & 34 & 27 & 24.5 & 3.61 & 19.4 \\
\hline & 3 & 4 & 4 & 4.7 & 0.81 & 2.5 \\
\hline & 3 & 3 & 3 & 18 & 18 & 18 \\
\hline \multirow{3}{*}{ mealy level 2} & 23 & 25 & 17 & 19.2 & 3.73 & 6.7 \\
\hline & 1 & 3 & 2 & 3.2 & 0.83 & 1.8 \\
\hline & 3 & 3 & 3 & 18 & 18 & 18 \\
\hline \multirow[t]{3}{*}{ mealy level 3} & 24 & 16 & 12 & 14.1 & 3.05 & 4.6 \\
\hline & 1 & 8 & 2 & 5.2 & 0.95 & 0.8 \\
\hline & 3 & 3 & 3 & 18 & 18 & 18 \\
\hline \multicolumn{7}{|l|}{ JONAGOLD } \\
\hline \multirow[t]{3}{*}{ mealy level I } & 46 & 45 & 30 & 26.2 & 5.42 & 25.5 \\
\hline & 2 & 4 & 3 & 4.2 & 1.79 & 1.7 \\
\hline & 3 & 3 & 3 & 18 & 18 & 18 \\
\hline \multirow[t]{3}{*}{ mealy level 2} & 40 & 45 & 19 & 22.1 & 5.84 & 16.1 \\
\hline & 1 & 1 & 1 & 2.3 & 0.90 & 2.1 \\
\hline & 3 & 3 & 3 & 18 & 18 & 18 \\
\hline \multirow[t]{3}{*}{ mealy level 3} & 28 & 37 & 15 & 21.8 & 4.81 & 13.8 \\
\hline & 2 & 8 & 1 & 3.3 & 1.31 & 1.9 \\
\hline & 3 & 3 & 3 & 18 & 18 & 18 \\
\hline ANOVA Factor: & $F$ values & $\mathrm{F}$ values & $F$ values & $\mathrm{F}$ values & F values & F values \\
\hline variety & $39.17^{* *}$ & $37.25^{* *}$ & $194.40^{* *}$ & $24.82 * *$ & $47.52^{* *}$ & $247,62 * *$ \\
\hline mealy level & $68.58 * *$ & $16.93^{* *}$ & $52.24^{* *}$ & $62.61^{* *}$ & $17.72 * *$ & $775.23^{* *}$ \\
\hline interaction. & $5.72^{* *}$ & 1.48 & 0.13 & $5.09 * *$ & $4.37^{* *}$ & $11.14^{* * *}$ \\
\hline
\end{tabular}


TABLE 4 .

LOADING FACTORS FOR THE SENSORY AND INSTRUMENTAL VARIABLES ON PRINCIPAL COMPONENT FACTORS (CORRELATION COEFFICIENT BETWEEN EACH VARIETY AND FACTOR); LOADINGS LESS THAN 0.7 OMITTED.

\begin{tabular}{|c|c|c|c|}
\hline FACTOR & & factor loadings & \\
\hline VARIABLES & FACTOR I & FACTOR 2 & FACTOR 3 \\
\hline Sensory & & & \\
\hline 2 Hardness & 0.87 & & \\
\hline 3 Crispness & 0.88 & & \\
\hline 4 Juiciness, chewing & & & \\
\hline 5 Toughness/chewiness & 0.72 & & \\
\hline 6 Density & 0.87 & & \\
\hline 7 Fibrous & & & \\
\hline 8 Granular & -0.76 & & \\
\hline 9 Floury & -0.84 & & \\
\hline 12 Green apple & 0.78 & & \\
\hline 13 Red apple & & & \\
\hline 14 Sweet & & 0.80 & \\
\hline $15 \mathrm{Acid} / \mathrm{sour}$ & 0.70 & & \\
\hline 17 Stale & -0.75 & & \\
\hline 20 Watery & & & \\
\hline 23 Unripe apple & & -0.74 & \\
\hline 28 Astringent & 0.75 & & \\
\hline 33 Yellow & -0.84 & & \\
\hline 35 Juicy internal appearance & & & \\
\hline Confined compression & & & \\
\hline $\mathrm{FI}$ & 0.89 & & \\
\hline DI & & & \\
\hline FD1 & 0.90 & & \\
\hline $\mathrm{F} 2$ & 0.89 & & \\
\hline Areal & 0.85 & & \\
\hline ELLAS & & & -0.80 \\
\hline Areac2 & 0.88 & & \\
\hline PERM & & & 0.80 \\
\hline GRAD $2: 3$ & 0.90 & & \\
\hline JUICE & & & \\
\hline Acoustic resonance & 0.76 & & \\
\hline FREQ & & & \\
\hline STIFF & 0.80 & & \\
\hline VEL & & & \\
\hline Explained Variance \% & 52.86 & 18.92 & 800 \\
\hline
\end{tabular}

The 2nd Principal factor is a variety axis, gathering mainly the sensory variables: sweetness $(14, \mathrm{R}=0.8)$ and unripe $(23, \mathrm{R}=-0.74)$. The variety aspect of this PC is extracted from the individuals representation (each point refers to 
the average value of a sample of a total number of 27; see Fig. 3) where the individuals of the variety 'Boskoop' are clearly scgregated from those of 'Cox' and 'Jonagold' individuals. The movement of the individuais within the plane (see arrows) indicates the loss of texture and juiciness for increasing mealiness stages.

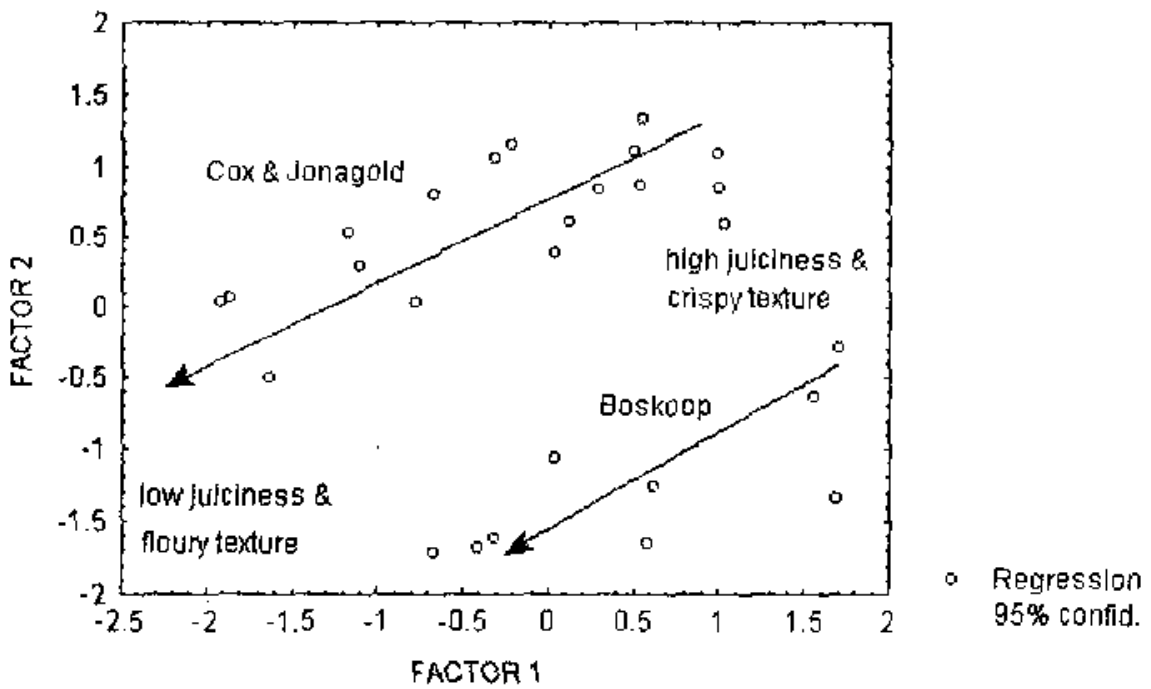

FIG. 3. REPRESENTATION OF THE 27 SAMPLES (3 VARIE']IES * 3 MEALINFSS STAGES * 3 REPLICATES) WITHIN THIE 1ST PRINCIPAL COMPONEN'IS PLANE

Some variables are well correlated within the 1 si -2 nd PC plane (see Fig. 4) though there is not a predominating relationship with any of the PC Factors. The level of representation of a variable can be measured through the cumulative determination coefficient also defined as commonalities (sec Table 5). This is the case for: confined compression: juice area (JUICE; $R^{2}=0.73$ ), acoustic impulse response: frequency (FREQ, $\left.R^{2}=0.86\right)$, sensory analysis: ist bite juiciness $(1$, $\left.R^{2}=0.83\right)$, juiciness during chewing $\left(4, R^{2}=0.88\right)$, coughness $\left(5, R^{2}=0.71\right)$, green colour $\left(12, R^{2}=0.93\right)$, red colour $\left(13, R^{2}=0.85\right)$, acid $\left(15, R^{2}=0.91\right)$, stale $\left(17, R^{2}=0.75\right)$, astringent $\left(28, R^{2}=0.87\right)$.

Further results obtained through the PC Analysis are:

(1) the sensory descriptors dealing with juiciness (1\&4) are highly correlated with the juice area (JUICE) measured under confined compression $(\mathrm{R}=0.85$ \& $R=0.87$, respectively); 


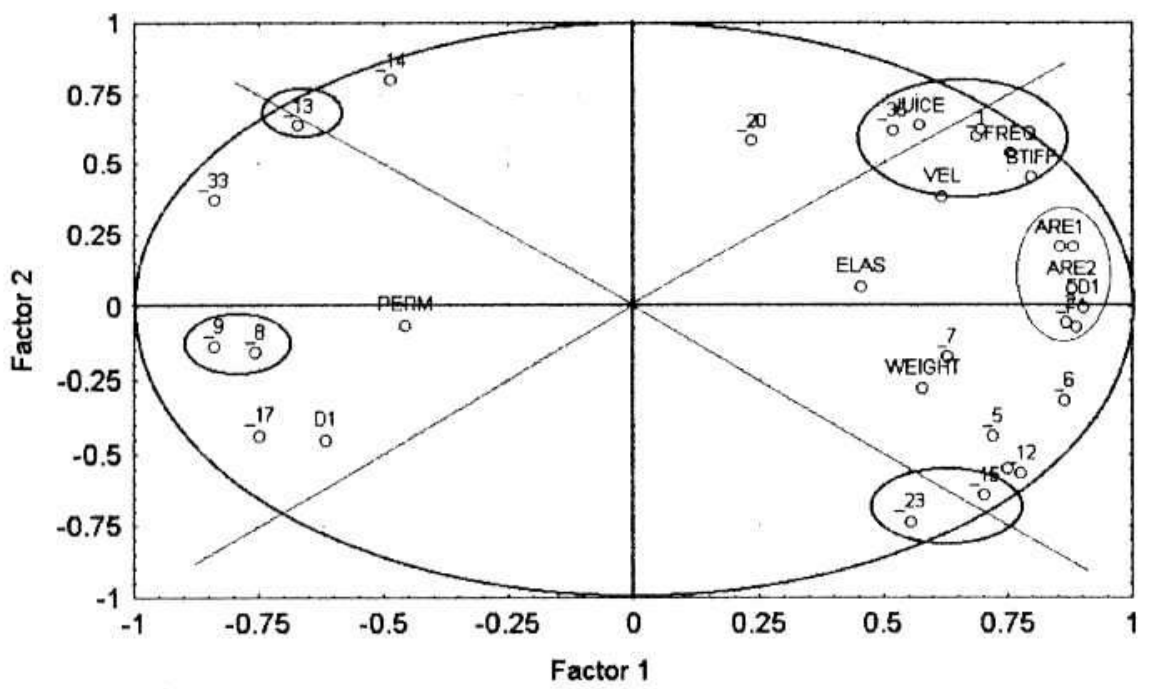

FIG. 4. VARIABLES REPRESENTATION WITHIN THE 1ST AND 2ND PRINCIPAL COMPONENTS PLANE

The best represented variables are those close to the borders of the circle

TABLE 5.

LEVEL OF REPRESENTATION (CUMULATIVE R ${ }^{2}$ ) OF THE SENSORY AND INSTRUMENTAL VARIABLES WITHIN THE MAIN 3 PRINCIPAL COMPONENTS OR FACTORS

\begin{tabular}{lccc}
\hline \multicolumn{1}{c}{ FACTOR ANALYSIS } & \multicolumn{3}{c}{ commonalties } \\
\hline \multicolumn{1}{c}{ VARIABLES } & FACTOR I & FACTOR I\&2 & $\begin{array}{c}\text { FACTOR } \\
\text { 1\&2\&3 }\end{array}$ \\
Sensory & & & \\
1 Juiciness, 1 ${ }^{\text {st }}$ bite & 0.473 & 0.831 & 0.847 \\
4 Juiciness, chewing & 0.488 & 0.876 & 0.887 \\
5 Toughness/chewiness & 0.520 & 0.715 & 0.788 \\
7 Fibrous & 0.399 & 0.428 & 0.690 \\
9 Floury & 0.573 & 0.598 & 0.743 \\
12 Green apple & 0.604 & 0.927 & 0.934 \\
13 Red apple & 0.449 & 0.854 & 0.867 \\
15 Acid/sour & 0.496 & 0.911 & 0.911 \\
23 Unripe apple & 0.309 & 0.851 & 0.851 \\
28 Astringent & 0.563 & 0.869 & 0.870 \\
35 Juicy internal appearance & 0.271 & 0.654 & 0.672 \\
Confined compression & & & \\
DI & 0.378 & 0.584 & 0.640 \\
JUICE & 0.328 & 0.734 & 0.743 \\
Acoustic resonance & & & \\
FREQ & 0.574 & 0.863 & 0.864 \\
\hline Explained Variance \% & 52.86 & 18.92 & 8.00 \\
\hline
\end{tabular}


(2) the sensory descriptor named as stale (17) is more highly correlated with the sensory attributes dcaling with juiciness $(1, \mathrm{R}=-0.84 \& 4, \mathrm{R}=-0.86)$ than with any other sensory parametcr;

(3) the variables Stiffness (STIFF) and Frequency (FREQ) measured through acoustic impulse response show a significant corrclation with the sensory attributes of juiciness (in all cases $r>0.8$ ); and

(4) the sensory descriptor named as floury is correlated with the variables forming the $1 \mathrm{st} P C(R=-0.87$ with the crispiness descriptor, 3$)$ and with the sensory attributes dealing with juiciness $(R=-0.78$ and $R=-0.71$, respectively). This fact confirms that the floury sensation in the mouth is related to a combination of loss of texture and of juiciness. We propose that a combination of at least two groups of sensory attributes, one describing lexture and one describing juiciness, should be used to characterise mealiness. The results obtained through the Factorial Analysis show that the sensory attributes: crispness, floury and juiciness during the first bite and during chewing should be preferred to characterise mealiness.

The 3rd Principal Component is formed mainly by the instrumental parameters: degree of permanent deformation (PERM) and the elastic deformation (ELAS) with $R=0.80$ and $R=-0.80$, respectively. This fact indicates the absence of any lincar relationship between these variables and those well correlated under the Ist Principal Components Plane.

The parameter named "iransmission velocity" (VEL) measured under ultrasound wave propagation is the parameter showing the weakest relationship with any other sensory or instrumental parameters measured. However, it correlates significantly with the resonance frequency $(R=0.85)$ and the deformation registered for $F l$ during confined compression $(R=0.72)$.

Assuming that sensory mealiness is a combination of the texture loss (low crispness and high floury, variables 3 and 9, respectively) and of the juiciness loss (low values at variables $I$ and 4), some prediction models have been developed using instrumental measurements (see Fig. 5 and 6 ) by stepwise linear regression.

Sensory modelling using the confined compression test:

1 st Bite Juiciness $=\mathrm{f}(\mathrm{JUICE}$, Area2, F1, D1) r2adjusted $=0.83$, linear Juiciness during chewing $=\mathfrak{f}$ (JUICE, Area2) radjusted $=0.74$, linear Crispness $=f(F D 1$, JUICE)

Floury $=\mathrm{t}($ Area2, DI, JUICE) r2adjusted $=0.67$, linear r2adjusted $=0.67$, exponential 
Sensory modelling using the acoustic impulse response test:

1st Bite Juiciness $=\mathrm{f}($ FREQ $)$

Jujciness during chewing $=\mathrm{f}$ (FREQ)

Crispness $=\mathrm{f}$ (STIFF)

Floury $=\mathrm{f}(\mathrm{STIFF})$ r2adjusted $=0.67$, linear

r2adjusted $=0.71$, linear

r2adjusted $=0.63$, linear

radjusted $=0.50$ linear

Sensory modelling combining the confined compression and the acoustic impulse response tests:

1st Bite Juiciness $=$ No improvement from confined compression modelling

Juiciness during chewing $=\mathrm{f}$ (JUICE, FREQ) r2adjusted $=0.85$, lineal

Crispness $=\mathrm{f}$ (STIFF, Area1, Arca2)

radjusted $=0.71$ lineal

Floury $=$ No improvement from confined compression modelling

Predicted vs, Observed Values

Dependent variable: juiciness during chewing

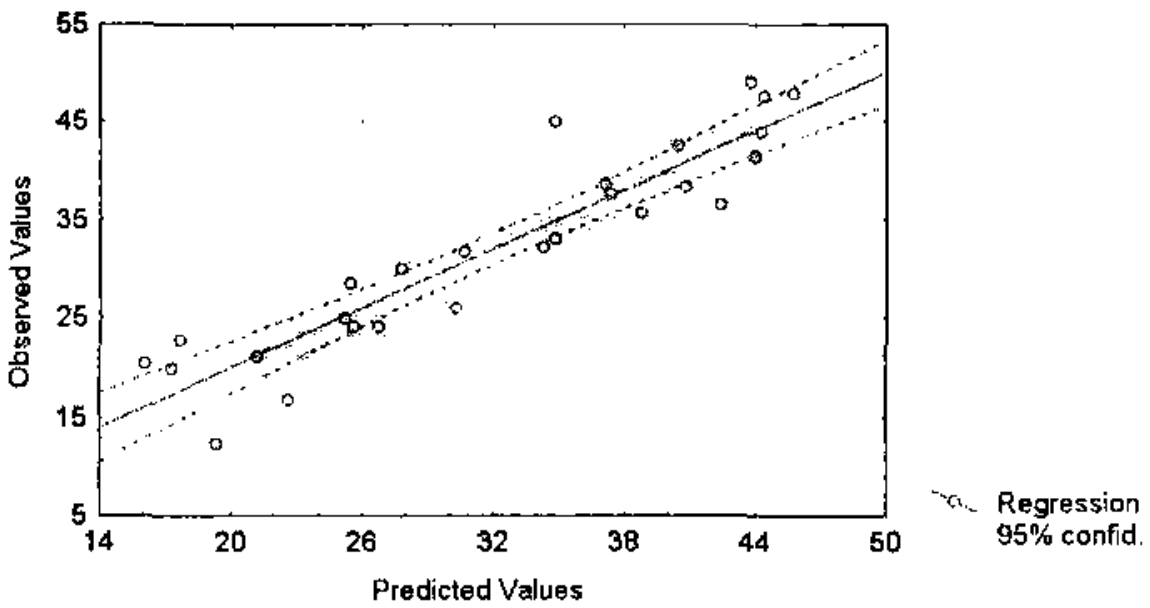

FIG. 5, SENSORY JUICINESS MODELLING USING TWO INSTRUMIZNTAL PARAMETERS: JUICE AREA (JUICE) REGISTERED UNDER CONFINED COMPRESSION AND RESONANCE FREQUENCY (FREQ) THROUGI] ACOUSTIC IMPULSE RESPONSE

The noded achieves a detemination coelficient of 0.85 . Solid line represents the regression model, broken lines are $95 \%$ contidence limits. 
Predicted vs. Observed Values

Dependent variable: crispiness

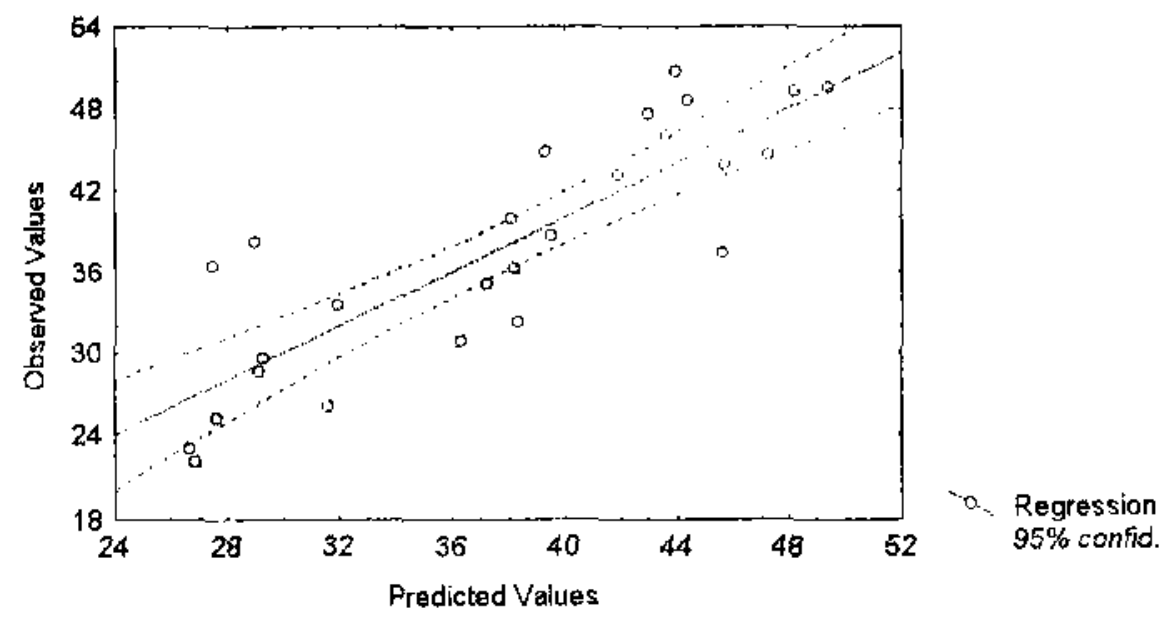

FIG. 6. SENSORY CRISPNESS MODELLIING USING THREE INSTRUMENTAI. PARAMETERS: ABSORBED ENERGY (AREA 1) AND RLSTITTUTION ENERGY (AREA 2) FROM CONFINED COMPRESSION, AND STIFFNESS (STIFF) FROM ACOUSTIC IMPUI.SE RESPONSE

The model achieves a determination coefficient of 0.71 . Solid line represents the regression model, broken lines are $95 \%$ confidence limits.

\section{CONCLUSIONS}

(1) Mealiness in apples is a negative texture quality aspect that cannot be described by a single sensory descriptor. It can be described through a combination of 4 sensory attributes which are: "crispness", "floury", "first bite juiciness" and "juiciness during chewing".

(2) A confined compression cylinder test and an acoustic impulse response test on whole apples, correjates highly with sensory attributes, crispness, floury, and juiciness (Ist bite and during chewing). Therefore these tests can be recommended as instrumental reference tests for mealiness assessment in apples.

(3) A Statistical modelling of the sensory attributes: crispness, floury, and juiciness (first bite and during chewing), was performed using a combination of parameters acquired from the confined compression test and the acoustic impulse response test. Determination coefficients not higher than 
0.85 for juiciness and than 0.71 for crispness were obtained with those statistical models. Although these statistical models do not allow at this stage to predict accurately the sensory attributes selected to describe mealiness, they should be used in further research to establish different commercial mealiness stages.

(4) Any improvement in instrumental assessment of mealiness should focus on the development of nondestruclive instrumental techniques. In this sense the acoustic impulse response gives encouraging results. Fusion of different instrumental techniques should always be considered as it can provide complementary information to better model the sensory aspects.

\section{ACKNOWLEDGMENTS}

Financed by the European Project FAIR CT-95-0302 entitled: Mealiness in fruit: consumers perception and means for detection.

\section{REFERENCES}

ABBOTT, J.A., MASSIE D.R., UPCHURCH B.L. and HRUSCHKA. W.R. 1995. Nondestructive sonic firmness measurement of apples. Trans. Am. Soc. Agr. Eng. 38, 1461-1466.

ABBOTT, J.A., WATADA, A.E. and MASSIE, D.R. 1984. Sensory and instrument measurement of apple texture. J. Am. Soc. Horti. Sci. 109, 221-228.

ARMSTRONG, P.R., ZAPP, H.R. and BROWN, G.K. 1990. Impulsive excitation of acoustic vibrations in apples for firmness determination. Trans. Am. Soc. Agr. Eng. 33, 1353-1359.

BARREIRO, P. and RUIZ-ALTISENT, M. 1997. Medida instrumental de la harinosidad en manzana. 11 Congreso lberoamericano de Ciencias Horticolas. Vilamoura 11-15 Marzo 1997.

DAILLANT-SPINNLER, D., MACFIE, H.J.H., BEYTS, P.K. and HEDDERLEY, D. 1996. Relationships between sensory properties and major preference directions of 12 varieties of apples from the southern hemisphere. Food Quality and Pref. pp. 112-126.

GALILI, N. and DE BAERDEMAEKER, J. 1996. Performance of Acoustic test methods for quality evaluation of agricultural products. ISMA 21 Conference, Sept. 1996 Leuven. 
HAARD, N.F. and SALUNKHE, D.K. 1975. Postharvest biology and handling of fruits and vegetables. pp. 47-51, AVI Publishing Company, Westport, CT.

HARKER, F.R. and HALLETT, L.C. 1992. Physiological changes associated with development of mealiness of apple fruit during cold storage. HortScience 27(12), 1291-1294.

HARKER, F.R., STEC, M.G.H., HALLET, I.C. and BENNETT, C.L. 1997. Texture of parenchymatous plant tissue: a comparison between tensile and other instrumental and sensory measurements of tissue strength and juiciness. Postharvest Biol. Technol. 11, 63-72.

LAPSLEY, K.G., ESCHER, F.E. and HOEHN, E. 1992. The cellular structure of selected apple varieties. Food Structure 11, 339-349.

MACFIE, H.J. and BRATCHELL, N. 1989. Designs to balance the effect of order of presentation and first-order carry-over effects in Hall Tests. J. Sensory Studies 4, 129-148.

MIZRACH, A., GALILI, N. and ROSENHOUSE, G. 1989. Determination of fruit and vegetable properties by ultrasonic excitation. Trans. Am. Soc. Agr. Eng. 32, 2053-2058.

PAOLETTI, F., MONETA, E. and SINESIO, F. 1993. Mechanical properties and sensory evaluation of selected apple cultivars. Lebensm.-Wis. u.-Technol. 26, 264-270.

SONE, T. 1972. Consistency of Foodstuffs. pp. 108-109, D. Reidel Publishing Co. 